Adam Twardosz

Doctoral Studies Programme

Faculty of Economics and International Relations

Cracow University of Economics

\title{
THE INFLUENCE OF GLOBAL IMBALANCES ON THE BUILD-UP OF THE CURRENT FINANCIAL CRISIS
}

\begin{abstract}
The issue of global imbalances already emerged in the pre-crisis era, albeit in a different context. Research was mostly concentrated on analysing how distortions in the external positions of the main countries would affect future turbulence on foreign exchange markets and in the real sector before reaching new equilibrium points. This article addresses the problem in a different manner by describing the causal link between monetary and fiscal expansion and the resulting increase in trade deficit. The process of reinvestment of foreign exchange reserves by surplus countries affects credit, stock and real estate markets, thus paving the way for future turmoil.
\end{abstract}

Keywords: global imbalances, exorbitant privilege, post-Bretton Woods system, financial crisis, current account, exchange rates.

\section{Introduction}

Over the past sixty years the world has witnessed an unprecedented growth of interdependence between countries - commonly referred to as globalisation.

Technological breakthroughs in telecommunications in the $1990 \mathrm{~s}$ accompanied by the lifting of trade barriers, promotion of free trade, movement of capital across borders, rapid technological advances in communication along with financial engineering, and the dispersal of risk among many institutions, led to excessive lending policies fuelling strong economic expansion with no apparent inflationary pressure. This reduction in the volatility of business cycles (known as "the Great Moderation"), first 
described by Chang-Jin and Nelson (1999), led to a debate during which several factors were identified as possible explanations. These included reduced taxation, changes in regulations, monetary policy (Summers 2005), and an element of "good luck".

No wonder, then, that the sudden emergence of the financial crisis in 2008 and especially its magnitude startled decision-makers and raised questions about the main culprits.

The aim of this article is to briefly present the factors responsible for the rise of the financial and economic crisis with strong emphasis on the influence of global imbalances on the creation of asset price bubbles in order to prove that the events of the years 2008-09 were not only a result of financial innovation accompanied by poor supervision but also of a global financial architecture dating back to the Bretton Woods and post-Bretton Woods era. Both the US dollar, being the centre of a system enjoying exorbitant privilege, as well as loose monetary and fiscal policies paved the way for the rise of global financial imbalances resulting in a credit boom and ending in the recent financial turmoil. More importantly, recent actions undertaken by central banks in order to overcome today's problems may turn out to be futile, without having addressed and solved the problem of global imbalances, and lead to a worse depression than that currently witnessed.

\section{Misleading Causes and Results - Factors Determining the Emergence of the Financial Crisis}

The deterioration in the performance of real global economy in the initial phase, comparable only to that of Great Depression, has raised much attention and sparked a vivid debate among Polish academics (see Sławiński 2007 and Rosati 2009). It has also been thoroughly researched by international financial institutions (e.g. BIS), during which the following direct factors were identified:

1. Loose monetary policy - conducted by the US authorities in the event of any major stock market crash or economic slowdown but never meeting a symmetrical response of tightening monetary conditions to the same extent in the case of overheating of the economy and the formation of an asset price bubble. This approach was justified by no apparent inflationary pressures (measured by CPI indexes) because these were channelled into stock and real estate markets. Therefore, the former FED governor Alan Greenspan concentrated on restoring balance to the system (meaning additional monetary expansion) after the burst of the asset price bubble 
rather than on counteracting soaring real estate or stock market prices as he believed that identification of the bubble at an early stage had no theoretical grounds. Okina and Shiratsuka (2001) supported his view by giving examples of several econometric models that suggested contradictory solutions during the stock market frenzy in Japan in the 1980s thus had no practical application. Moreover, according to the research of Bordo and Murshid (2002) - the transmission mechanism during the Great Depression was different to the one in the pre-financial crisis era. Even though some attention was given to identifying similarities, the authors still advocated that today's core of the world economy was formed by a greater number of countries, which should translate into the higher resilience and stability of the system. Franklin and Gale (2002) addressed an interesting and widely-discussed agency problem claiming that interlinkages on stock markets should help to diminish the risk of asset price bubble formation without the interference of the central bank. They believed in the common sense of agents being interested in undertaking such actions so that they would not result in the severance of their employment agreements.

2. Loose fiscal policy - as the BIS (2012) indicates: "fiscal positions in many advanced economies were already on an unsustainable path before the financial crisis. The crisis led to a significant further deterioration in fiscal sustainability by increasing fiscal deficits and debt. As a result, financial markets and credit rating agencies took a more critical view of sovereign credit risk. Government debt and deficits that had been tolerated before the crisis were no longer considered sustainable".

3. Easy credit conditions and subprime lending - channelling inflationary pressures into real estate and stock markets. Misleading stability lasting for several years despite monetary expansion, decreasing yields and returns on traditional financial instruments (bonds and deposits) had been fuelled by subprime lending - i.e. granting loans to high-risk borrowers with poor credit histories and reduced repayment capacities (for more about the influence of subprime lending on real estate prices, see Mayer \& Pence 2008). The system operated on the assumption of the ongoing rise in asset prices being the collateral of the mortgages provided.

4. Financial innovation - i.e. the creation of instruments (CDOs Collateralised Debt Obligations) issued by SPVs (Special Purpose Vehicles) up to two trillion USD (for more, see Sławiński 2007) helping to trade and hedge credit risk by spreading it into many institutions - meant to evade regulations, allow banks to maximise profits, and safeguard the system's stability at the same time. Falling real estate prices and increased defaults 
among borrowers questioned the valuation of CDOs and resulted in their being written off by their holders. This led to a crisis of confidence resulting in credit tightening and thus affecting the real economy (for more, see BIS 2009).

5. Lack of supervision and prudent regulation - assessing the risks connected with previously mentioned financial innovation and credit expansion (Bernanke 2010).

6. Burst of the asset price bubble - affecting the non-real sector of the economy by decreasing the value of the collateral to the loans granted by financial institutions as well as influencing their balance sheets, thus resulting in credit tightening for the real economy. Additionally, a sudden drop in asset prices affects the real economy via wealth effects, i.e. decreased spending due to the lowering of perceived wealth by individuals and companies (for more about the wealth effect during the Great Depression, see Mishkin 1978).

Even though the above list is used to depict a causal link, it cannot be complete without addressing the issue of global imbalances, which along with monetary policy should be recognised as very important factors responsible for the rise of asset price bubbles and their subsequent bursting, which resulted in the recent financial mayhem.

The term "global imbalances" has evolved over the past 150 years and at the beginning referred to trade deficits being financed by financial account surpluses.

Until the inter-war period, the global economy was hardly influenced by these imbalances for the following reasons:

- underdeveloped countries and colonies with a very small share in global GDP were responsible for running trade deficits whereas the source of capital was located in the core of the global economy (Bordo 2005),

- the gold standard forced early adjustment processes for macroeconomic policy through the outflow of gold and human labour,

- sterling used to be a major reserve currency with a strong background of trade surpluses recorded by the UK economy.

The problem of global imbalances has gained importance in the post-war era due to:

- the revolution in telecommunications and tightening and intensifying trade relations,

- the appearance of fiduciary money in lieu of the gold standard. The adjustments can be prolonged for a longer period of time and hence appear more abruptly, occurring through the exchange rate and international reserve channels, thus affecting relative prices instead of adjustments at the level of nominal prices (Obstfeld 2004), 
- change in the list of "deficit countries". The most powerful economies have become the greatest debtors instead of creditors.

Therefore, the term "global imbalances", previously understood as the US trade deficit and the corresponding surplus of Asian countries, has been replaced with a more general definition proposed by Bracke et al. (2008) which sees global imbalances as "external positions of systematically important economies that reflect distortion or entail risk for the global economy, i.e. the deficit side (US) and surplus side (Asia, Germany, oil exporters) accompanied by an analysis of developments in the main surplus countries, first and foremost Asian economies and oil-exporting countries. Additionally, the focus on current account positions was complemented by a focus on the domestic and financial imbalances in the economies concerned" (see Fig. 1 and 2). Domestic and financial imbalances have come as a reference to the results of research indicating interdependence between trade and fiscal deficits in the US in the 1990s (this subject will be discussed in a later part of this article).

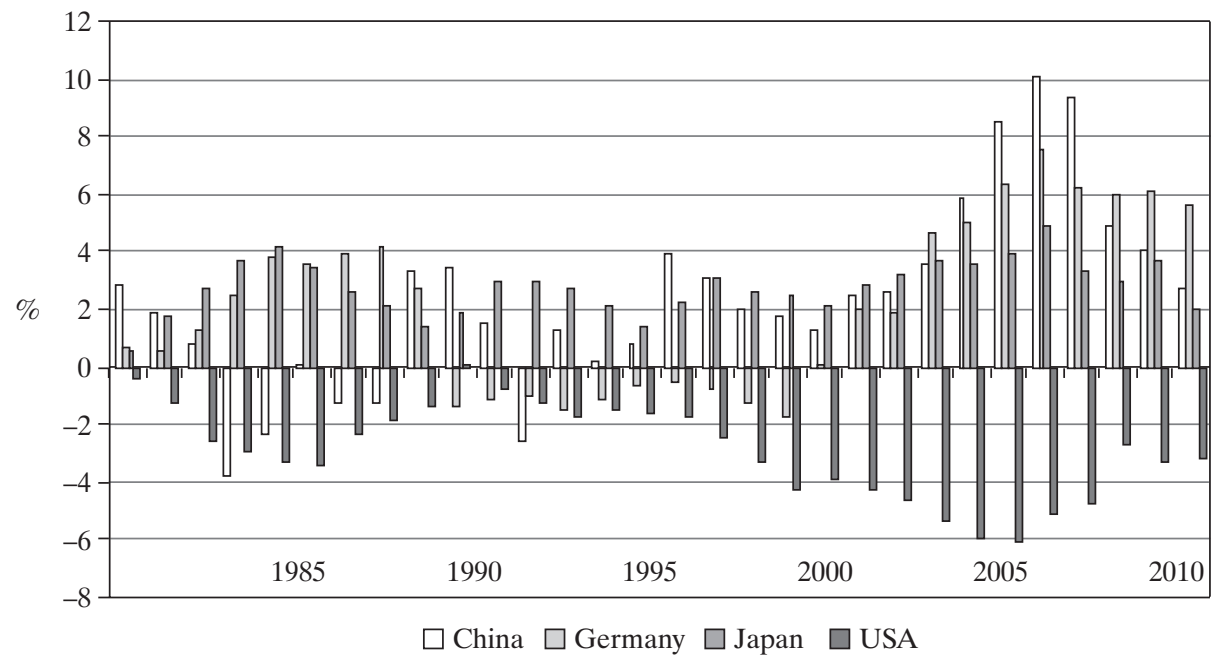

Fig. 1. Current Account Result of Main Surplus and Deficit Countries, 1980-2011 Source: http://databank.worldbank.org/ddp/home.do?Step=1\&id=4, March 2013.

More recent studies concentrate mostly on identifying the risks connected with global imbalances and indicate:

a) disorderly adjustment - total financial mayhem resulting from uncontrolled depreciation of the USD, higher interest rates and risk 
premiums, increased inflation rates, lower potential output (Blanchard \& Milessi-Feretti 2011),

b) exchange rate volatility (Angeloni et al. 2011),

c) increased risk of banking crisis (Barrell et al. 2010),

d) protectionism (BIS 2011).

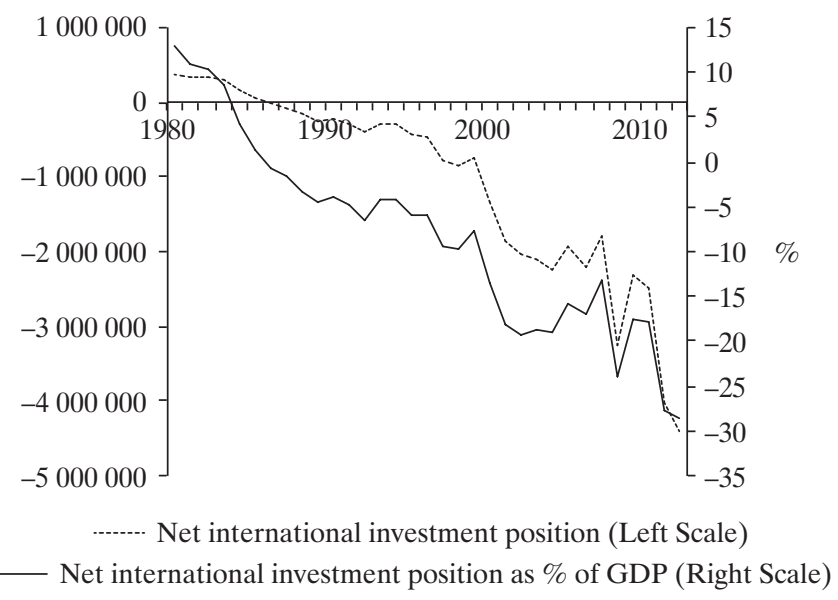

Fig. 2. US Net Investment Position (in Mio USD) and as \% of GDP Source: Bureau of Economic Analysis.

The BIS annual report (2011) also indicates the importance of gross financial flows, which entail great risk in the global financial system via the interconnected balance sheets of different financial institutions. Usually, the attributes of assets (outflows) are not the same as those of liabilities (inflows), which translates into currency, liquidity and credit risk.

In light of the above overview of the problem of global imbalances, I examine their hypothetical influence on the build-up of the global financial and economic crisis in Fig. 3 and in the following summarised scenario:

1) first stage:

- a stock market crash or negative shock lead to a sudden depreciation of assets and deteriorate activity in the real sector via different mechanisms such as wealth effects, credit channels, and balance sheet transmission channels,

- a stock market crash and subsequent slowdown in economic activity attract a response from both monetary and fiscal policies,

- monetary and fiscal expansion bring the economy on track but cause a rise of global imbalance and asset price hikes; 
2) second stage:

- in the case of countries with global reserve currencies, the rapidly growing build-up of asset positions in USD by non-residents with increased demand for their shares, bonds and other assets, thus not affecting the exchange rate of these currencies,

- the inflow of additional money to the banking system and the money multiplier mechanism lead to credit expansion, further fuelling rising asset prices and the economy,

- the growth of the economy becomes unsustainable due to large internal (rising inflationary pressure) and external imbalances,

- the gloomy prospects for the economy undermine euphoria on stock and other asset markets, finally ending in the burst of the bigger than previously created bubble and resulting in global financial mayhem via the balance sheet effects of recipient and donor countries.

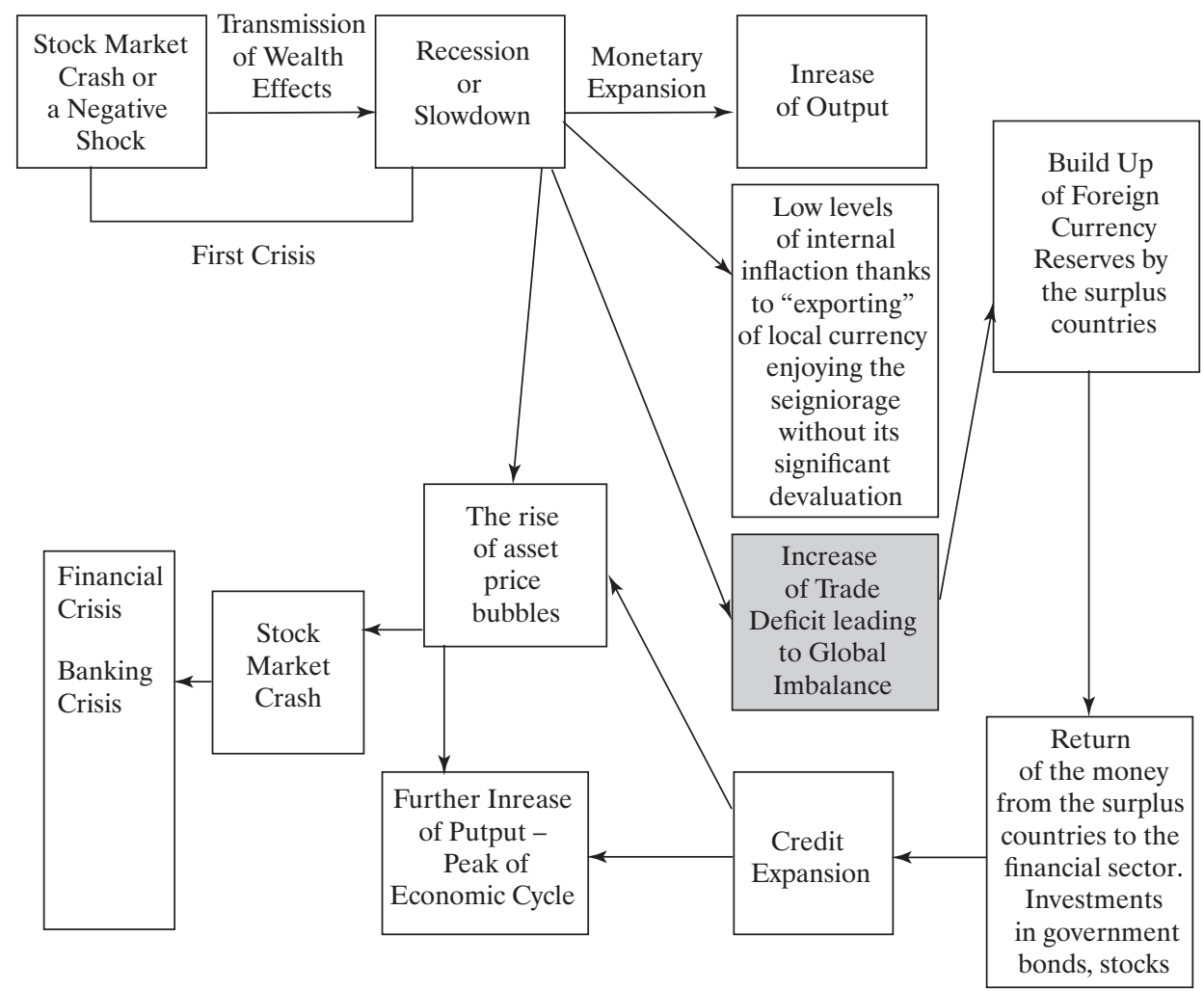

Fig. 3. Global Imbalances and Development of the Financial Crisis

Source: Twardosz (2013, p. 41). 
The above hypothesis of global imbalances arising from both monetary and financial expansions resulting in the build-up of foreign reserves by surplus countries being invested back, particularly in the US, and leading to the rise of asset price bubbles, will be verified in subsequent sections of this paper.

\section{Bretton Woods - When It All Started}

The decision to make the US dollar the sole currency convertible to gold, thus making it the main reserve currency, was the primordial sin of the system. As Europe required large amounts of funds for its post-war reconstruction, the US ran a huge current account surplus, which resulted in an increased demand for US currency for international transactions. As a result, the US authorities pursued domestic macroeconomic policy without paying attention to growing imbalances reflected in the increasing current account deficit. This situation referred to as "seignorage" (or "exorbitant privilege") helped to stimulate the local economy without the risk of inflationary pressure as it was "exported" to the world in the form of fiduciary money.

Soon, the shortage of US dollars was replaced by an excess. However, no changes in macroeconomic policy were introduced. In the early 1960s, despite support from Belgium, France, Holland, Switzerland and Italy, the US had to resort to the sale of its gold reserves on the London market in order to maintain its pegged value against the USD. Moreover, the G-10 countries agreed to cease exchanging their currency reserves into gold.

All these steps proved futile and forced the US to suspend convertibility of the USD into gold, which was followed by a series of devaluations and finally the collapse of the Bretton Woods System (in 1973).

\section{From the Post-Bretton Woods Financial Architecture to the Current Financial Crisis}

The fall of the Bretton Woods System brought chaos onto the world's financial and currency markets as the exchange rates of currencies comprising the past system had to be adjusted in order to reach a new dynamic equilibrium point. Soon, most of the developed world adopted free floating as the dominant currency regime.

In theory, the new system should have brought external macroeconomic stability as any global imbalance would be overcome by an adjustment in the currency exchange rate, thus promoting exports from countries facing a current account deficit and limiting their imports. However, it did not live up to expectations for three main reasons: 
1. High mobility of capital - the revolution in telecommunications and the process of lowering currency restrictions encouraged and increased the mobility of capital, thus hindering the pursuit of an independent monetary policy - this problem is known as the Impossible Trinity Trillemma and was introduced for the first time by Obstfeld and Taylor (1997) and discussed widely in subsequent years (e.g. Obstefeld, Shambaugh \& Taylor 2004).

2. Continuous problem of "seignorage" - the introduction of the free floating regime has not resolved the problem of the US dollar's dominance because it still remains the main reserve currency in the world's foreign exchange reserves, enjoying growing demand from newly-developed and developing countries. However, its supremacy was threatened after the introduction of the Euro in 1999. Since then, the composition of foreign exchange reserves has been constantly changing in favour of the new European currency (Fig. 4).

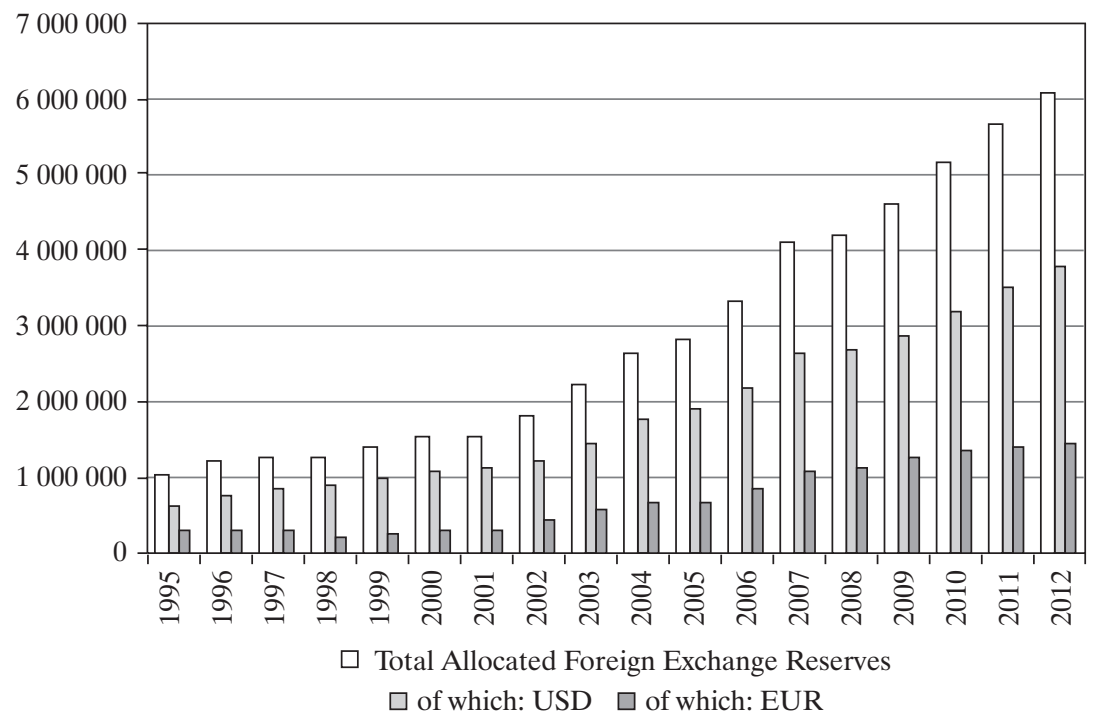

Fig. 4. Composition of Allocated Foreign Exchange Reserves (in Mio USD), 1995-2012

Source: author's own calculations on the basis of IMF (2008) data.

3. Pricing of traded commodities in USD. This forces underdeveloped countries with high export ratios of raw materials or commodities to keep their own currencies closely tied to the US dollar instead of using currency baskets (e.g. Russia, major oil exporters, etc.). 
To sum up: post-war financial architecture based on a single currency, i.e. the US dollar, has provided the US authorities with a powerful tool to stimulate the economy without questioning its external stability. The subsequent sections of this paper identify and examine the relative influence of both monetary and fiscal policies on the rise of global imbalances, which eventually translated into hikes in asset prices and the emergence of the financial crisis.

\section{Do Loose Monetary and Fiscal Policy Influence the Trade Balance?}

The answer to this question may be very ambiguous. In the case of a Mundell-Flemming model of an open economy with a flexible exchange rate regime, monetary expansion leads to a lowering of the interest rate, thus encouraging the outflow of capital. This results in a depreciation of the local currency, leading to the promotion of exports and the substitution of imports with domestic products. In such a case, monetary expansion per se does not imply a rise in the trade deficit.

However, this situation cannot be applied to the US, which enjoyed seignorage in the 1980s and 1990s. Monetary and fiscal expansion usually served to invigorate local demand but did not affect the USD exchange rate to the same extent as it would have affected other currencies. As a result, the economy would steam up and the current account deficit widen.

At the same time, the growing US economy gave more credibility to the US dollar, which was even more eagerly bought by non-residents even though the trade deficit worsened.

The direct relationship between monetary policy and the trade balance has not been widely examined. However, it does find empirical confirmation in the research of Gust, Leduc and Sheets (2008). The authors try to verify the extent of the response of the nominal trade balance to various shocks hitting the economy, including a monetary expansion, by considering three alternative assumptions:

- the benchmark version assumes that foreign exporters price to the market and home exporters impose producer pricing,

- the second scenario, referred to as LOW ERPT, assumes both home and foreign exporter pricing,

- and the final scenario, referred to as HIGH ERPT, assumes that both home and foreign exporters are engaged in producer pricing processes. 
Table 1

Response of Trade Prices and Quantities to Monetary Expansion

\begin{tabular}{l|c|c|c|c|c}
\hline $\begin{array}{c}\text { Monetary } \\
\text { Expansion }\end{array}$ & $\begin{array}{c}\text { Real } \\
\text { Exchange } \\
\text { Rate }\end{array}$ & Absorption & Real Trade & $\begin{array}{c}\text { Terms } \\
\text { of Trade }\end{array}$ & $\begin{array}{c}\text { Nominal } \\
\text { Trade } \\
\text { of GDP) }\end{array}$ \\
\hline High ERPT & 0.58 & 1.41 & -0.49 & 0.65 & -0.12 \\
\hline Benchmark & 0.64 & 1.54 & -0.88 & 0.25 & -0.12 \\
\hline Low ERPT & 1.00 & 1.68 & -2.44 & -1.57 & -0.09 \\
\hline
\end{tabular}

Source: Gust, Leduc and Sheets (2008).

The findings are presented in Table 1 and show that the influence of monetary expansion on the trade balance is highest in the case of the benchmark and high ERPT scenarios.

\section{The Influence of Fiscal Policy on the Trade Balance}

The first series of studies carried out by Roubini (1988), Baxter (1994) and Normandin (1999) indicated, depending on the models used, a deterioration of the trade balance in response to an increase in the budget deficit. These studies differed only in estimating the strength of the effect, which varied between 0.22 and 0.98 (in other words, an increase in the fiscal deficit by $1 \%$ of GDP resulted in a widening of the trade balance by $0.22-0.98 \%$ of GDP). The above research was conducted in 1980 and in the 1990s on the basis of earlier data from the early globalisation era, and the parameters were estimated on the basis of the data for 18 OECD countries on the current account to GDP ratio, the budget deficit to GDP ratio (equivalent to the change in public sector net debt), and on the investment (including fixed capital formation and the change of inventories) to GDP ratio in the 1960-85 period.

The results of testing the model indicate that in most countries both variables (increase in budget deficit and investment) are significant and lead to a worsening of the current account balance.

However, the latest studies indicate a much more modest influence:

Cavallo (2005a) analyses a two-country model (home and foreign country) with households, the private sector and government, and introduces the assumptions of the overlapping generations (OLG) model. He also assigns numerical values to the linearised model of economy so that it is consistent with the post-war experience of the US economy and comes to 
the conclusion that an increase in government expenditure on tradable goods is indeed responsible for a significant deterioration in the trade and current account balance. On the other hand, the study indicates that the rise of expenditure on labour services has a minor influence on the trade balance and accounts for $0.05 \%$ of GDP for each increase of budget deficit by $1 \%$ of GDP.

In their study, Erceg, Guerrieri and Gust (2005) indicate a higher impact of $0.12 \%$ but still well below the values calculated in the early $1990 \mathrm{~s}$. On the other hand, Roubini and Soyoung (2004) report an opposite influence of loose fiscal policy on the trade balance, showing that in some cases a very strong crowding out effect of private investment by government expenditure can offset the effect of fiscal expansion on trade balance by inducing interest rates hikes and limiting domestic investments.

\section{Do Loose Monetary Policy and Global Imbalance Influence Asset Prices?}

A monetarist theory in its orthodox version argues that each monetary expansion usually affects nominal variables leaving the real ones unchanged. This means that the level of output remains the same and the change of prices reflects the monetary expansion.

Today, this link may sometimes not seem clear as there are many examples of countries witnessing higher growth of monetary aggregates without significant inflationary pressure. There are, of course, several explanations for this fact on the basis of the main equation provided by monetarist theory itself. The stability of prices measured by CPI indices may arise from lower money velocity or a smaller volume of transactions. Moreover, despite the orthodox view, monetary expansion may turn out to be effective where there is an output gap, hence resulting in a growth of the real values of GDP without a rise in inflationary pressure.

However, assuming the stability of velocity or the volume of transactions, the price stability witnessed during monetary expansion should have a different basis - either due to foreign trade and the leaking of excess money out of the country resulting in a rise in external imbalance or the build-up of inflationary pressure on other markets such as the real estate or stock market. In the case of the US, the leaking of excess money out of the country could not be the main source of price stability, as the money would instantly return to the country in the form of investment in US government securities and corporate stocks, thus affecting the real economy (Table 2). 


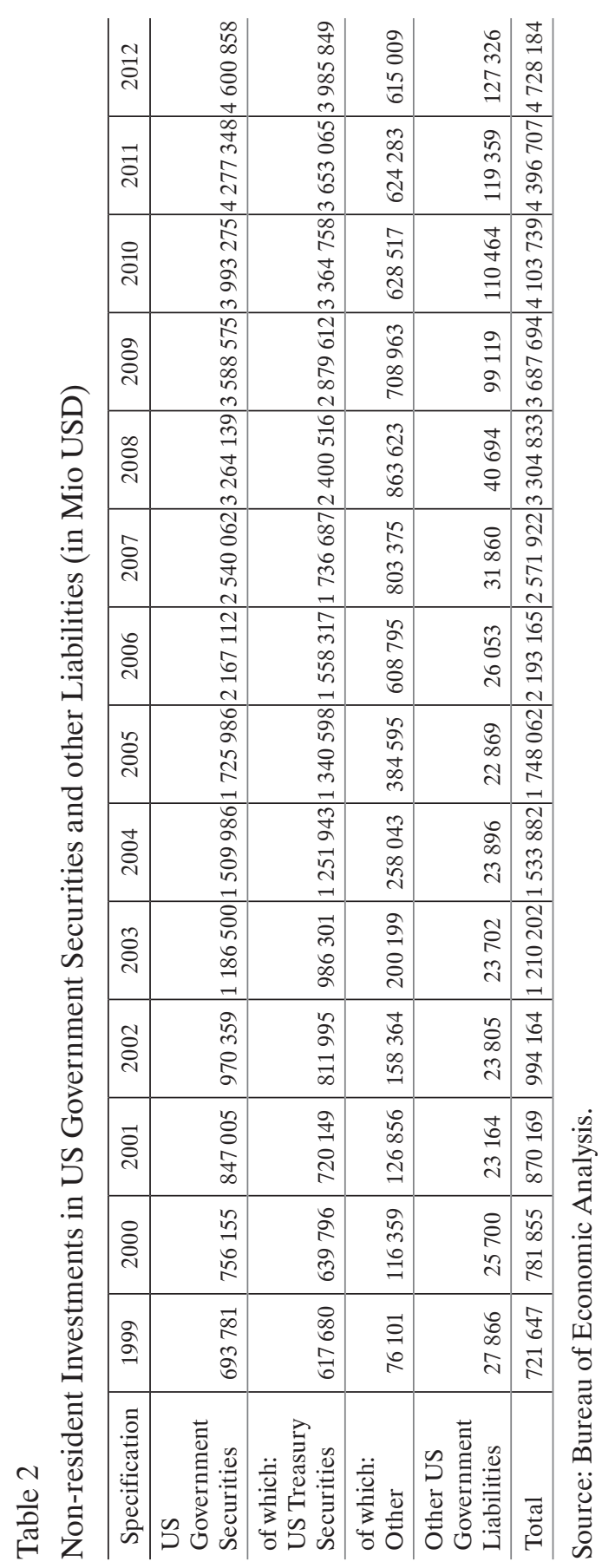


In this case, it was asset prices that must have absorbed the increased money supply. The idea of a link between asset prices and monetary expansion is not new and was already identified by economists in the 1970s.

Also, some recent empirical research provides arguments to support the above-mentioned mechanism. Herrera and Perry (2001), in their work examining Latin American countries, find a relationship between domestic credit growth and bubble episodes taking place with a long lag. They emphasise that almost all episodes of asset price bubbles were preceded by a credit boom.

The same conclusion follows from research on the Japanese crisis carried out by Shiratsuka (2003). Among the many factors responsible for the rise of the bubble, such as financial deregulation, inadequate risk management, taxation and regulations supporting further price hikes on real estate markets, monetary easing also has a place. In this case, the Bank of Japan was also mislead by false price stability despite a large increase in the money supply. "As a result, it was widely argued that the statistical relationship between money supply and prices had become unstable and this argument gradually prevailed".

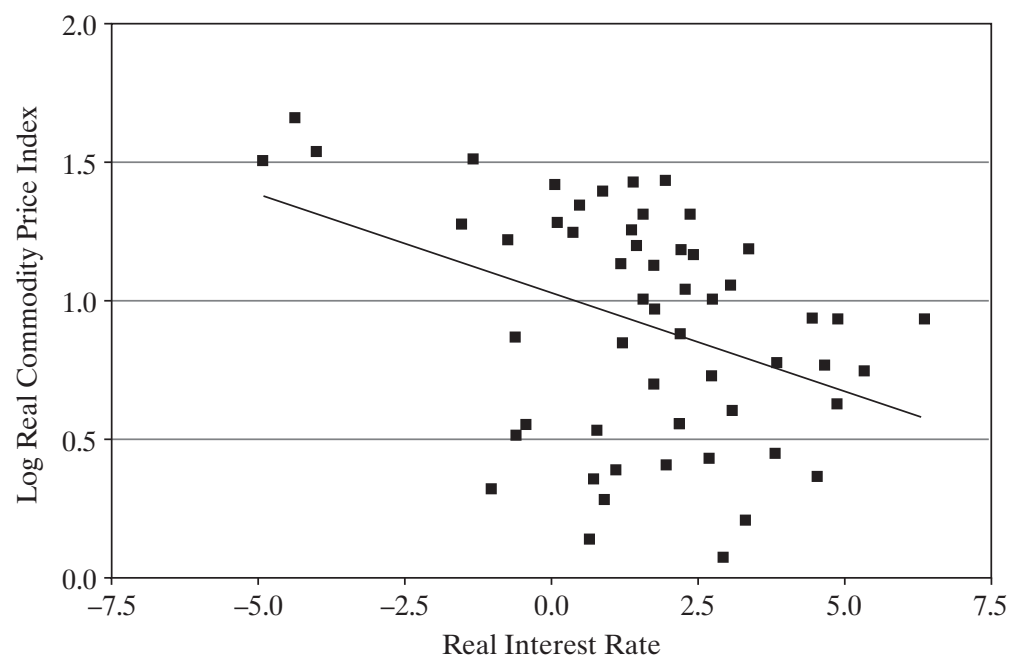

Fig. 5. Dow Jones Commodity Price Index and Real Interest Rates, Annual 1950-2005

Source: Frankel (2008). 
Frankel (2008) reports a statistical significance (of 5\%) between real interest rates and asset prices. An increase of $1 \%$ in the real interest rate results in a $6 \%$ drop in asset prices (Fig. 5).

To conclude: the above examples of empirical research confirm the hypothesis about a link between loose monetary and fiscal policies and the rise of trade imbalances finally translating into asset price hikes. These findings also raise a question about current monetary stimuli, which may, according to the mechanism described above, pave the way for a new crisis. This issue is addressed in the final section of this paper.

\section{Methods of Overcoming the Current Financial Crisis - Will History Repeat Itself?}

The collapse of investment funds in 2007, the uncertain status of Fannie Mae and Freddie Mac, and finally the bankruptcy of Lehman Brothers in 2008 eventually translated into increased credit risk resulting in further credit tightening. The interbank money markets for the USD, EUR, CHF and other major currencies ceased to perform their main function due to lack of confidence, which caused market rates to soar to levels far in excess of official interest rates.

As a result of this credit crunch, the risk of collapse of the world's financial system was formidable, which forced major central banks to respond promptly. As the initial constants regarding the velocity of money circulation and money demand changed, central banks started pumping liquidity into the world's financial system. The purpose of this was to try to avoid the mistakes of the Great Depression of the 1930s when, according to Bernanke (1983), monetary policy did not properly address the series of bank runs that destabilised the financial markets and money supply and hence affected aggregate demand and translated into a subsequent depression in 1930-32. Therefore, first interest rates were cut and then additional instruments were introduced, including the opening of quotas of unlimited money or finally resorting to such unorthodox monetary policy as quantitative easing - i.e. the purchase by the central bank of bonds or other financial instruments from commercial banks (for more, see BIS 2008, Chailloux et al. 2008).

After a closer examination of the FED's balance sheet for the period of the last five years (see Fig. 6), one can clearly see the massive response in the autumn of 2008. In a very short period of time the FED's total assets almost tripled, raising concerns about future price stability. The governors 
of the FED and other central banks have emphasised their readiness to withdraw from stimulus measures once the economy starts showing strong signs of recovery, but as of today only a $22 \%$ reduction in QE policy has been introduced (based on decisions made by FOMC in December 2013 and January 2014). Yet at the same time the ECB and Bank of Japan continue to expand their loose monetary policies in order to invigorate local economies.

More importantly, the recent actions of the FED and ECB are having little impact on the rise of global imbalances, which can be attributed to the following:

a) asset markets act as sterilisers to QE policy, absorbing additional liquidity (see Fig. 9),

b) financial institutions are very uneasy about future prospects and are thus unwilling to increase credit to both the private and corporate sector and prefer to keep excess funds in the ECB's "deposit facility". Therefore, despite high levels of QE, the M3 Broad Money Indices (see Tables 3 and 4) have recorded very moderate or low growth over the past six years (European Central Bank 2014),

c) private investors concentrate on deleveraging their debts to the level of their current assets and income instead of increasing their consumption, which would partially generate higher imports,

d) The US has reduced greatly its dependence on natural resources over the past five to ten years by substantially increasing the extraction of domestic shale gas and oil.

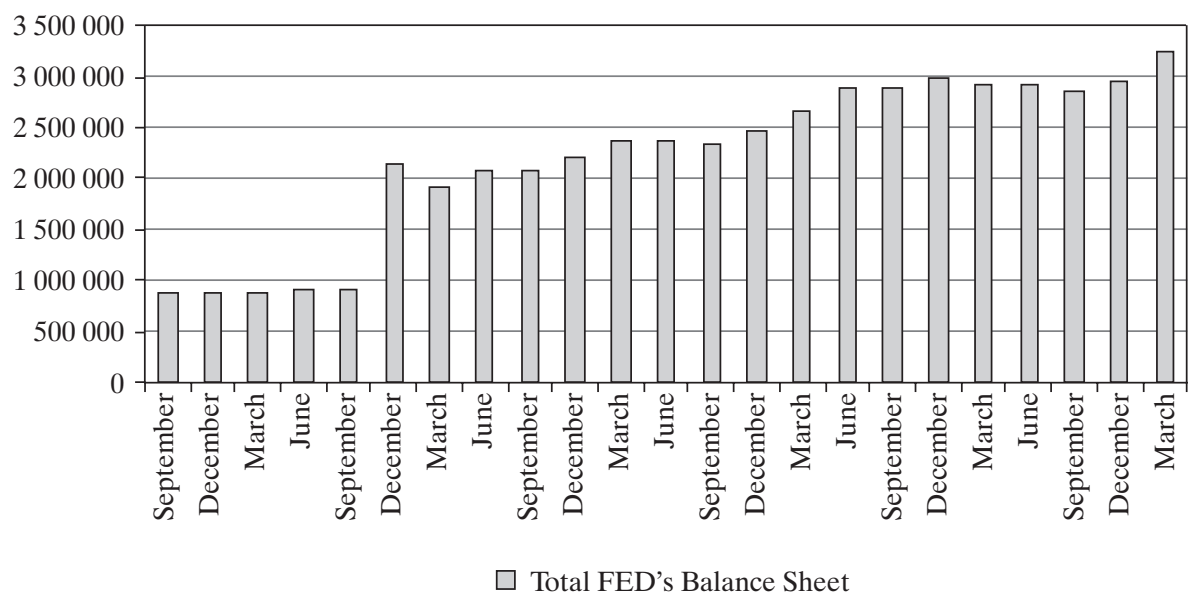

Fig. 6. Total FED's Balance Sheet (in Mio USD), 2007-13

Source: http://www.federalreserve.gov/monetarypolicy/bst_recenttrends.htm, March 2013. 
Table 3

Narrow Money (M1) Index $2010=100$, SA

\begin{tabular}{c|c|c|c|c|c|c}
\hline \multicolumn{1}{c|}{ Country } & 2008 & 2009 & 2010 & 2011 & 2012 & 2013 \\
\hline United States & 82.3 & 94 & 100 & 115.4 & 132.7 & 146.3 \\
\hline Euro area (18 countries) & 83.5 & 92 & 100 & 102.2 & 106.4 & 113.7 \\
\hline
\end{tabular}

Source: data extracted on 16 March 2014 from OECD.Stat.Extracts.

Table 4

Broad Money (M3) Index $2010=100$, SA

\begin{tabular}{l|c|c|c|c|c|c}
\hline \multicolumn{1}{c|}{ Country } & 2008 & 2009 & 2010 & 2011 & 2012 & 2013 \\
\hline United States & 90.4 & 97.6 & 100 & 107.3 & 116.5 & 124.4 \\
\hline Euro area (18 countries) & 97.4 & 101.1 & 100 & 101 & 103.8 & 105.7 \\
\hline
\end{tabular}

Source: data extracted on 16 March 2014 from OECD.Stat.Extracts.

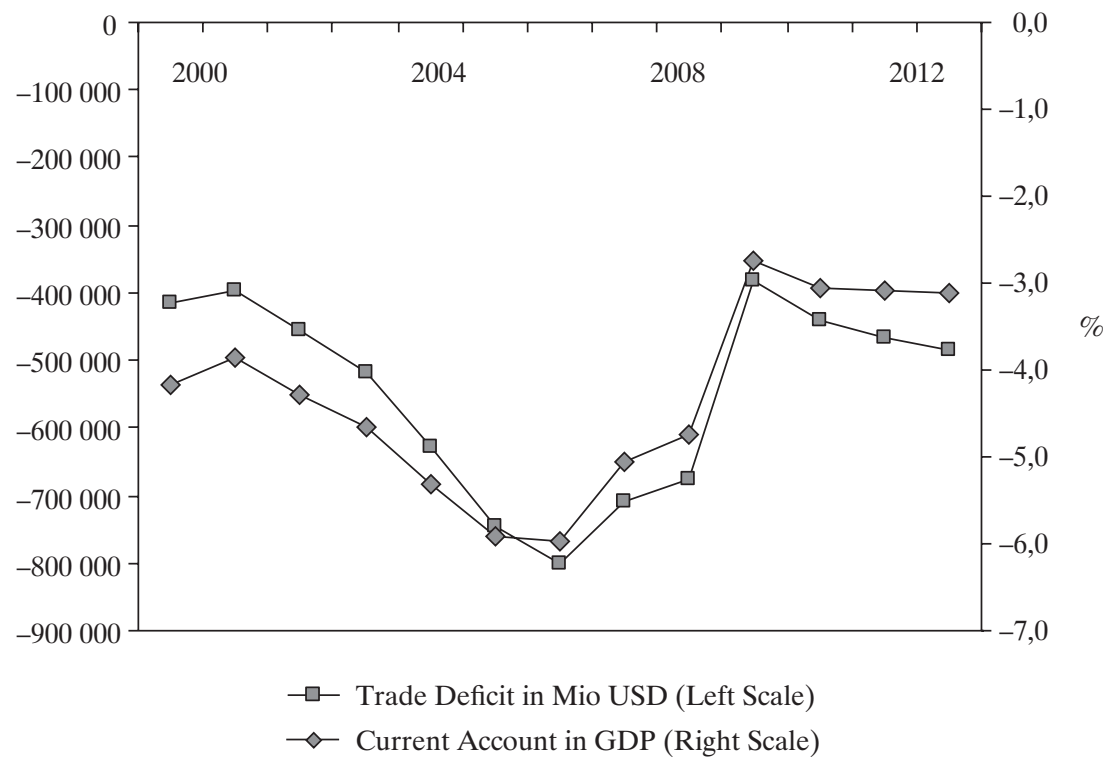

Fig. 7. US Trade (in Mio USD) and Current Account Deficit, 2000-13

Source: International Monetary Fund, World Economic Outlook Database, October 2012. 


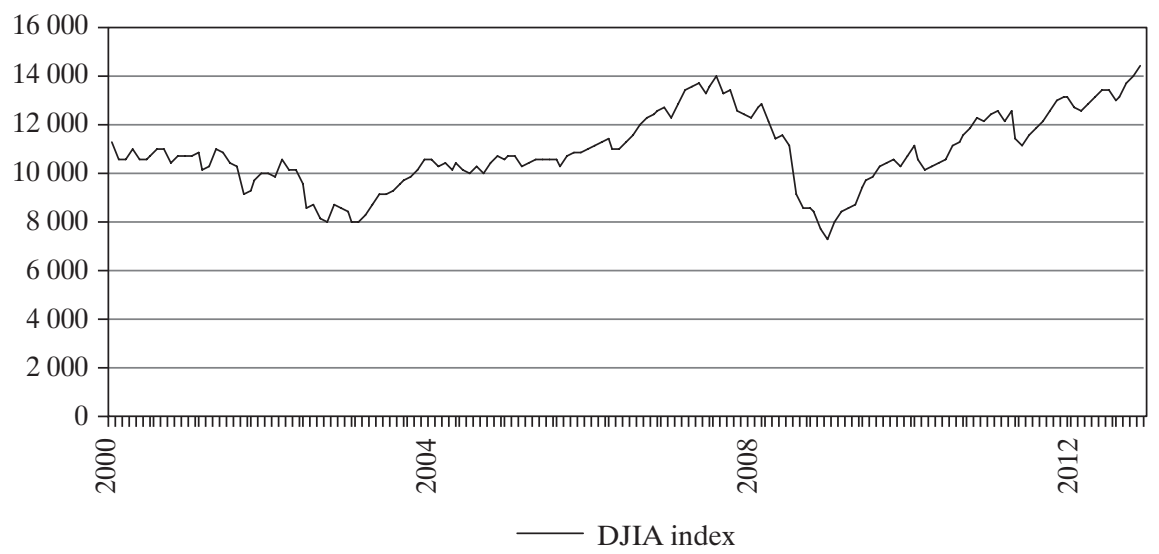

Fig. 8. Stock Prices - DJIA, 2000-13

Source: http://research.stlouisfed.org/fred2/series/DJIA/downloaddata, March 2013.

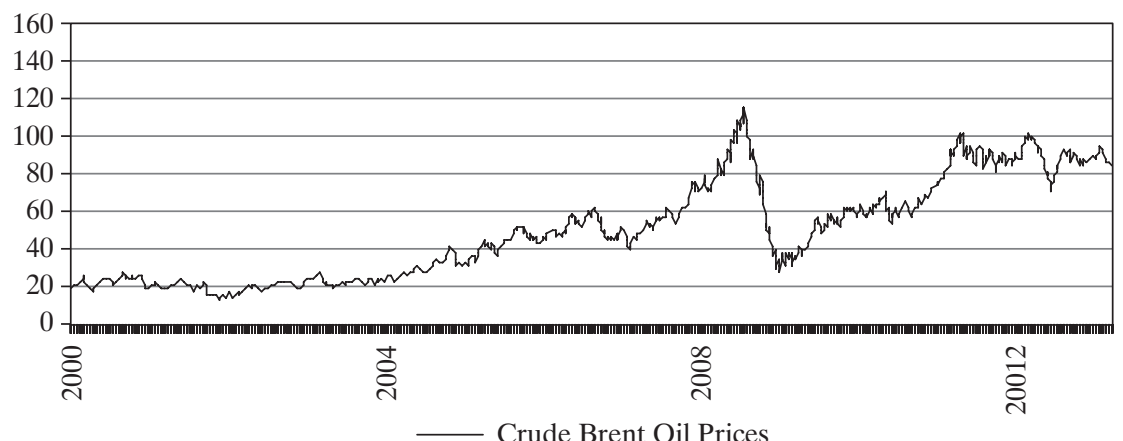

Fig. 9. Oil Prices, 2000-13

Source: http://www.quandl.com.

Nevertheless, today's rebound of asset prices and commodities, along with the healing of the US economy, may finally translate into growing demand, inflation and trade deficit (see Fig. 7-9), once again posing the risk that loose monetary policy along with growing global imbalances will lead to another build-up of asset price bubbles which, when they burst, will result in new global turmoil. 


\section{Future Prospects}

In the midst of the current financial crisis, the future of the global economy remains unclear. In this section I sketch several possible scenarios and outcomes.

In the benchmark scenario, a big response from both monetary and fiscal policies puts the economy back on track, but with a high possibility of either of the following happening:

- a surge in inflation resulting from the late withdrawal of central banks from their previous loose policies (including quantitative easing), leading to a sudden change of monetary policy causing more problems for creditors with rising bad loans and write offs. In such a case, financial institutions dealing with a balance sheet crisis will not provide the necessary capital to SMEs but will resort to the safest partners - big corporations and government. This will hamper the supply-side of economy and may drive it into long lasting stagflation;

- monetary and fiscal expansion will be channelled into asset markets, thus providing a false idea of price stability and encouraging central banks to pursue monetary expansion for longer. The economy will steam up but eventually the burst of another asset price bubble will cause an even more severe financial crisis and recession.

The second scenario assumes a willingness to solve the problem of global imbalance. In this case, China and other big "surplus" countries decide to substantially revalue their currencies, which also leads to a rise in global inflation (as the price of goods imported from those countries will increase) but at the same time to a reduction in the US fiscal and trade deficits and a narrowing of the global imbalance, thus reducing the risk of substantial hikes in asset prices and their subsequent collapse. Assuming a moderate response of the FED and other central banks to lower price stability (real interest rates will not be set very high, at least at the beginning of the process), the world witnesses the slow deleveraging of debts and the repair of balance sheets. The economy does not return too fast to a high growth path, but the supply side of the economy is spared as SMEs are not cut off from credit markets. This fact will be an important factor paving the way for rapid growth in future once the process of debt deleveraging is complete ${ }^{1}$.

${ }^{1}$ Fic and Orezgani (2013) provide a very interesting analysis of the risks and implications for EU policy under different scenarios of a reduction in global imbalances. For reasons of space, these are not presented here. 
The third scenario is based on the second one but includes additional steps taken at the international level to introduce a new currency system. This will remove the major drawback of the current system - the dominant status of the US dollar - by:

- either introducing a currency basket (used for the diversification of foreign exchange reserves),

- or using SDR or a new settlement unit (based on currency baskets) for the purpose of unilateral compensation of trade and current account deficits.

It is worth mentioning that in each scenario the world witnesses at least a moderate rise in inflationary pressure. More importantly, this period of higher inflation and relatively low real interest rates is needed to clear balance sheets and deleverage debts.

The only possibility of avoiding inflation without either driving the economy into a deflationary cycle or inducing another asset bubble burst would require both:

- perfect timing by central banks in ending their quantitative easing policy and reducing their balance sheets so that excess money does not spill over into the banking system,

- a technological breakthrough in the US (a positive supply shock) resulting in higher productivity and exports leading to a narrowing of global imbalance.

Last but not least, in all cases the world economy will have to face a negative supply shock coming from commodities markets which, depending on the strength of the economic recovery, will have a different impact on price stability. China's industrialisation and entry onto global markets significantly increases the demand for oil, gas, and other natural resources. Energy consumption is set to triple over the next fifty years (for more, see Campbell 2002 and 2003, Nur 2004), which poses a clear threat to the global economy in a form of a supply shock that can only be overcome by finding efficient, alternative sources of energy. Recent advances in hydraulic fracturing and horizontal completions have enabled shale gas to be extracted on a large scale, which may eventually help to decrease US dependence on natural resources from other countries, reducing its external deficit at the same time. This positive supply shock may become the first milestone in combating the problem of the notorious US trade deficit, remedying the problem of global imbalances and promoting long term growth. 


\section{Final Conclusions}

The main goal of this paper was to provide evidence that the current financial crisis is a result of global imbalances. Empirical research confirms the hypothesis that monetary and fiscal expansion increases the trade deficit, which via a process of reinvestment of foreign exchange reserves by "surplus" countries affects the credit, stock and real estate markets. This mechanism is additionally amplified by the US enjoying "exorbitant privilege", although its impact needs to be further examined.

These findings may lead to the conclusion that the role of monetary policy in stabilising business cycles is diminishing due to its side effects on the external financial position of countries overusing this tool. Nevertheless, one must not forget that every crisis has multiple causes. Thus, the promotion of long-term global stability would require a complete policy mix that should include, but not be limited to: the creation of a new financial architecture based on several reserve currencies instead of just one; the valuation of foreign currency exchanges on the basis of current trade balance rather than being a result of the speculative movement of capital (e.g. by means of the Tobin tax); addressing the issue of gross flow controls; and a new institutional framework including prudent regulations and the supervision of financial institutions accompanied by the finding of new energy sources.

\section{Bibliography}

Angeloni, I. et al. (2011) "Global Currencies for Tomorrow. A European Perspective". Economic Paper No. 444, July. Brussels: European Commission.

Bank of Canada (2010) Speech by Mr Lorenzo Bini Smaghi, Member of the Executive Board of the European Central Bank, at the workshop on "Monetary Policy: Recent Experience and Future Directions", Bank of Canada, Toronto, 9 April, http://www. bis.org/review/r100413e.pdf.

Barrell, R., Davis, E. P., Karim, D. and Liadze, I. (2010) "Does the Current Account Balance Help to Predict Banking Crises in OECD Countries?” http://niesr.ac.uk/ sites/default/files/publications/260310_134627.pdf.

Baxter M. (1994) “International Trade and Business Cycles”. RCER Working Paper 390. University of Rochester, Centre for Economic Research (RCER).

Bernanke, B. (1983) "Nonmonetary Effects of the Financial Crisis in Propagation of the Great Depression”. American Economic Review 73: 257-76.

Bernanke, B. (2010) "Causes of the Recent Financial and Economic Crises before the Financial Crisis Inquiry Commission”. Washington DC, 2 September, http://www. federalreserve.gov/newsevents/testimony/bernanke20100902a.htm. 
BIS (2008) Bank for International Settlements "Central Bank Operations in Response to Global Financial Turmoil”, CGFS Paper No. 31. Committee on the Global Financial System.

BIS (2009) Bank for International Settlements “79th Annual Report, 1 April 2008-31 March 2009". Basel.

BIS (2011) Bank for International Settlements "81" Annual Report, 1 April 2010-31 March 2011". Basel.

BIS (2012) Bank for International Settlements "82 ${ }^{\text {nd }}$ Annual Report, 1 April 2011-31 March 2012". Basel.

Blanchard, O. and Milessi-Feretti, G. M. (2011) "Why Should Current Account Balances Be Reduced?" IMF Staff Discussion Note, March.

Bordo, M. (2005) "Historical Perspective on Global Imbalances". NBER Working Paper 11383.

Bordo, M. and Murshid, A. (2002) "Globalisation and Changing Patterns in the International Transmission of Shocks in Financial Markets". NBER Working Paper 9019.

Bracke, T., Bussiere, M., Fidora, M. and Straub, R. (2008) “A Framework for Assessing Global Imbalances". Occasional Paper Series of the ECB, January.

Campbell, C. J. (2002) "Petroleum and People". Population and Environment 24.

Campbell, C. J. (2003) Oil Depletion - The Heart of the Matter. Ireland: Association for the Study of Peak Oil \& Gas (ASPO).

Cavallo, M. (2005a) "Government Consumption Expenditures and the Current Account”. FRBSF Working Paper 2005-03.

Cavallo, M. (2005b) "Understanding the Twin Deficits: New Approaches, New Results". FRBSF Economic Letter No. 2005-16.

Chailloux, A., Gray, S., Kluh, U, Shimizu, S. and Stella, P. (2008) "Central Bank Response to the 2007-2008 Financial Market Turbulence: Experiences and Lessons Drawn". IMF Working Paper WP/08/210.

Chang-Jin, K. and Nelson C. (1999) "Has the US Economy Become More Stable? A Bayesian Approach Based on a Markov-switching Model of the Business Cycle". Review of Economics and Statistics.

Erceg, C, Guerrieri, L. and Gust, C. (2005) "Expansionary Fiscal Shocks and the Trade Deficit”. International Finance Discussion Paper No. 825, January. Board of Governors of the Federal Reserve System.

European Central Bank (2014). Introductory statement to the press conference by Mario Draghi with Q\&A, January, https://www.ecb.europa.eu/press/pressconf/2014/html/ is140109.en.html.

Fic, T. and Orezgani, A. (2013) "Growth Risks for the EU Emanating from Global Imbalances". Economic Paper No. 483, April. Brussels: European Commission.

Frankel, J. A. (2008) “The Effects of Monetary Policy on Real Commodity Prices" in J. Campbell (ed.) Asset Prices and Monetary Policy. Chicago: University of Chicago Press.

Franklin, A. and Gale, D. (2002) "Asset Price Bubbles and Market Interlinkages". Federal Reserve Bank of Chicago, conference materials, 22-24 April.

Gust, C., Leduc, S. and Sheets, N. (2008) "The Adjustment of Global External Balances: Does Partial Exchange-Rate Pass-Through to Trade Prices Matter?" FRBSF Working Paper 2008-16, June. 
Herrera, S. and Perry, G. (2001) "Tropical Bubbles. Asset Prices in Latin America, 1980-2001”. Policy Research Working Paper 2724, World Bank.

IMF (2008) "Currency Composition of Official Foreign Exchange Reserves (COFER)", http://www.imf.org/external/np/sta/cofer/eng/index.htm.

Mayer, C. and Pence, K. (2008) "Subprime Mortgages: What, Where, and to Whom?". NBER Working Paper 14083.

Mishkin, F. S. (1978) “The Household Balance Sheet and the Great Depression”. Journal of Economic History 37: 918-37.

Normandin, M. (1999) "Budget Deficit Persistence and the Twin Deficits Hypothesis". Journal of International Economics 49: 171-93.

Nur, A. (2004) Oil Future and War Now: A Grim Earth-Sciences Point of View. Geophysics Department, Stanford University.

Obstfeld, M. (2004) "External Adjustment”. NBER Working Paper 10843, October.

Obstefeld, M. and Taylor, A. M. (1997) “The Great Depression as Watershed. International Capital Mobility over the Long Run”. NBER Working Paper 5960, March.

Obstfeld, M., Shambaugh, J. C. and Taylor, A. M. (2004) "The Trillemma in History. Trade-offs among Exchange Rates, Monetary Policies and Capital Mobility”. NBER Working Paper 10396, March.

Okina, K. and Shiratsuka, S. (2001) "Japan's Experience with Asset Price Bubbles. Is It the Case for Inflation Targeting?" in W. Hunter, G. Kaufmann and M. Pomerleano (eds) Asset Price Bubbles. The Implications for Monetary, Regulatory and International Policies. Cambridge, MA: MIT Press.

Rosati, D. (2009) "Przyczyny i mechanizm kryzysu finansowego w USA" [The causes and mechanism of the financial crisis in the US]. Ekonomista 3: 315-51.

Roubini, N. (1988) "Current Account and Budget Deficits in an Intertemporal Model of Consumption and Taxation Smoothing. A Solution to the Feldstein Horioka Puzzle?". NBER Working Paper 2773.

Roubini, N. and Soyoung, K. (2004) Twin Deficits or Twin Divergence? Fiscal Policy, Current Account, and Real Exchange Rate in the US. Korea University and University of New York, mimeo.

Shiratsuka, S. (2003) "Asset Price Bubble in Japan in the 1980s: Lessons for Financial and Macroeconomic Stability”. Discussion Paper 2003-E-15, IMES Bank of Japan.

Sławiński, A. (2007) "Przyczyny i konsekwencje kryzysu na rynku papierów wartościowych emitowanych przez fundusze sekurytyzacyjne" [The causes and consequences of the crisis on the market for securities issued by securitisation funds], http://www.rynkifinansowe.pl/subprime_CDO.pdf.

Summers, P. M. (2005) "What Caused the Great Moderation? Some Cross-country Evidence". Economic Review of the Federal Reserve Bank of Kansas City.

Taylor, J. B. (1995) “The Monetary Transmission Mechanism: An Empirical Framework", Journal of Economic Perspectives 9.

Twardosz, A. (2013) “Wielka depresja a współczesny kryzys finansowy - podobieństwa i różnice. Perspektywy dla globalizacji” [The Great Depression and the current financial crisis - a comparative analysis and perspectives for future globalisation]. Zeszyty Naukowe Uniwersytetu Ekonomicznego w Krakowie 903. Kraków: Cracow University of Economics, pp. 35-53. 


\section{Abstract}

\section{Wpływ nierównowag globalnych na rozwój obecnego kryzysu finansowego}

Nierównowagi globalne były przedmiotem licznych badań już w okresie poprzedzającym ostatni kryzys finansowy i gospodarczy, jednakże dotyczyły innych aspektów. Badania te koncentrowały się głównie na analizie wpływu nierównowag bilansu płatniczego na rynki walutowe oraz na sektor realny. W niniejszym artykule podjęto problem nierównowag globalnych w odmienny sposób - przez opisanie ciągu zdarzeń przyczynowo-skutkowych, z którego wynika, że to właśnie nadmierna ekspansja monetarna i fiskalna skutkowały wzrostem deficytu bilansu płatniczego Stanów Zjednoczonych. Proces inwestowania rosnących nadwyżek finansowych przez główne kraje eksportujące miał wpływ na rynki kredytowe oraz aktywów (giełda i nieruchomości), co doprowadziło do przyszłych zawirowań gospodarczych.

Słowa kluczowe: nierównowagi globalne, seignorage, system po Bretton Woods, kryzys finansowy, rachunek bieżący, kursy walutowe. 